\title{
Gerakan “pendikar” menuju SMPN 5 Banjarbaru digandrungi masyarakat
}

\section{The "pendikar" movement towards SMPN 5 Banjarbaru is loved by the public}

\author{
Undi Sukarya $^{1}$ \\ ${ }^{1}$ SMPN 5 Banjarbaru \\ Email: undisukarya8@gmail.com ${ }^{1}$
}

\section{INFO ARTIKEL}

Diterima : 30 April 2021

Disetujui : 27 Mei 2021

Tersedia secara Online Mei 2021

\author{
Alamat Korespondensi: \\ Undi Sukarya \\ SMPN 5 Banjarbaru \\ Jl. Ambulung, Guntungmanggis, Kec. \\ Landasan Ulin, Kota Banjar Baru, \\ Kalimantan Selatan \\ E-mail: undisukarya8@gmail.com
}

\begin{abstract}
ABSTRAK
Kegiatan pembentukan karakter peserta didik adalah Iman dan taqwa (turunan nilai religius dan integritas); Akhlak mulia (turunan nilai religius dan integritas); Cinta tanah air (turunan dari nilai nasionalis dan integritas); Cinta lingkungan (turunan dari nilai nasionalis dan religius), dan Kewirausahaan (turunan dari nilai mandiri dan gotong royong). Penguatan pendidikan karakter yang didasari oleh lima nilai utama tersebut belum memiliki bentuk implementasi yang jelas di SMP Negeri 5 Banjarbaru, sehingga penerapan penguatan karakter peserta didik belum dapat diterapkan dengan efektif. Keberhasilan penguatan karakter peserta didik juga belum dapat terukur dengan baik karena indikatornya yang belum terlalu jelas. Selain itu, ekspektasi masyarakat pada institusi sekolah selama ini terus meningkat seiring dengan peningkatan pengaruh media sosial pada karakter peserta didik. Institusi sekolah diharapkan dapat secara efektif membentuk karakter peserta didik (soft skill) disamping memberikan ilmu pengetahuan dan keterampilan (hard skill).
\end{abstract}

Kata kunci: Pendikar, Karakter, Keterampilan.

The character building activities of students are faith and piety (derivatives of religious values and integrity); Noble morals (derivatives of religious values and integrity); Love the homeland (derivative of nationalist values and integrity); Love for the environment (derivative of nationalist and religious values), and Entrepreneurship (derivative of the values of independence and mutual cooperation). Strengthening character education which is based on these five main values does not yet have a clear form of implementation at SMP Negeri 5 Banjarbaru, so the application of strengthening the character of students cannot be implemented effectively. The success of strengthening the students' accruals also cannot be measured properly because the indicators are not too clear. In addition, community expectations for school institutions have been increasing along with the increasing influence of social media on the character of students. School institutions are expected to be able to effectively shape the character of students (soft skills) in addition to providing knowledge and skills (hard skills).

Key words: Pendikar, character, skills. 


\section{PENDAHULUAN}

Pembentukan karakter merupakan salah satu fungsi utama pendidikan seperti yang termaktub dalam UU Nomor 20 Tahun 2003 tentang Sistem Pendidikan Nasional. Pada pasal 1 UU Sisdiknas menyebutkan bahwa Sistem Pendidikan Nasional bertujuan untuk membantu peserta didik membentuk potensi dirinya untuk memiliki kekuatan spiritual keagamaan, pengendalian diri, kepribadian, kecerdasan, akhlak mulia, serta keterampilan yang diperlukan dirinya, masyarakat, bangsa dan Negara. Lebih jauh lagi, pada pasal 3 menyebutkan bahwa Sisdiknas juga berfungsi mengembangkan kemampuan dan membentuk watak serta peradaban bangsa yang bermartabat dalam rangka mencerdaskan kehidupan bangsa, bertujuan untuk berkembangnya potensi peserta didik agar menjadi manusia yang beriman dan bertakwa kepada Tuhan Yang Maha Esa, berakhlak mulia, sehat, berilmu, cakap, kreatif, mandiri dan menjadi warga Negara yang demokratis serta bertanggung jawab.

Berdasarkan fungsi dan tujuan pendidikan nasional, jelas bahwa pendidikan di setiap jenjang, termasuk Sekolah Menengah Pertama (SMP) harus diselenggarakan secara sistematis guna mencapai tujuan tersebut. Hal tersebut berkaitan dengan pembentukan karakter peserta didik sehingga mampu bersaing, beretika, bermoral, sopan santun dan berinteraksi dengan masyarakat. Sekolah Menengah Pertama sebagai salah satu jenjang pendidikan juga memiliki fungsi dasar yang sama serta memiliki peranan vital dalam pembentukan karakter peserta didik. Hal ini ditegaskan dengan Peraturan Pemerintah Nomor 17 tahun 2010 tentang Pengelolaan Penyelenggaraan Pendidikan pada Pasal 17 ayat 3 yang menyebutkan bahwa pendidikan dasar bertujuan membangun landasan bagi berkembangnya potensi peserta didik agar menjadi manusia yang (a) beriman dan bertakwa kepada Tuhan Yang Maha Esa; (b) berakhlak mulia dan berkepribadian luhur; (c) berilmu, cakap, kritis, kreatif dan inovatif; (d) sehat, mandiri dan percaya diri; (e) toleran, peka sosial, demokratis dan bertanggung jawab.

Penguatan karakter juga merupakan salah satu inti dari Gerakan Revolusi Mental (GRM) yang diwujudkan dalam gerakan Penguatan Pendidikan Karakter (PPK) (Mashud, 2015). Gerakan ini merupakan pendidikan di sekolah untuk memperkuat karakter siswa melalui harmonisasi olah hati (etik), olah rasa (estetis), olah pikir (literasi), dan olahraga (kinestetik) dengan dukungan pelibatan public dan kerja sama antara sekolah, keluarga, dan masyarakat. Dimensi pengolahan karakter meliputi olah hati (etik) untuk membentuk individu yang memiliki kerohanian mendalam, beriman dan bertakwa; olah rasa (estetis) untuk membentuk individu yang memiliki integritas moral, rasa kesenian dan berkebudayaan; olah pikir (literasi) untuk membentuk individu yang memiliki keunggulan akademis sebagai hasil pembelajaran dan pembelajar sepanjang hayat, serta olahraga (kinestetik) untuk membentuk individu yang sehat dan mampu berpartisipasi aktif sebagai warga Negara. Gerakan PPK memiliki lima nilai utama karakter prioritas PPK yaitu Religius, Integritas, Nasionalis, Gotong Royong dan Mandiri.

Penguatan pendidikan karakter yang didasari oleh lima nilai utama tersebut belum memiliki bentuk implementasi yang jelas di SMP Negeri 5 Banjarbaru, sehingga penerapan penguatan karakter peserta didik belum dapat diterapkan dengan efektif. Keberhasilan penguatan karakter peserta didik juga belum dapat terukur dengan baik karena indikatornya yang belum terlalu jelas. Selain itu, ekspektasi masyarakat pada institusi sekolah selama ini terus meningkat seiring dengan peningkatan pengaruh media sosial pada karakter peserta 
didik. Institusi sekolah diharapkan dapat secara efektif membentuk karakter peserta didik (soft skill) disamping memberikan ilmu pengetahuan dan keterampilan (hard skill).

Oleh karena itu, dengan berdasarkan pada lima nilai utama gerakkan PPK, disusun program "Pendidikan Karakter (PENDIKAR)" dari SMP Negeri 5 Banjarbaru yang berpusat pada lima kegiatan utama yaitu: Iman dan Takwa (Turunan Nilai Religius dan Integritas), Akhlak Mulia (Turunan Nilai Religius dan Integritas), Cinta Tanah Air (Turunan Nilai Nasionalis dan Integritas), Cinta Lingkungan (Turunan Nilai Gotong Royong dan Religius) dan Kewirausahaan (Turunan Nilai Mandiri dan Gotong Royong).

Rumusan masalah dalam penelitian ini adalah Apakah PENDIKAR dari SMPN 5 Banjarbaru dapat dengan efektif mewakili nilai implementasi nilai utama karakter prioritas PPK?; Apakah PENDIKAR dari SMPN 5 Banjarbaru dapat dengan efektif membantu peserta didik membentuk karakternya berdasarkan nilai utama karakter prioritas PPK?; Apakah PENDIKAR dari SMPN 5 Banjarbaru dapat meningkatkan animo masyarakat terhadap SMPN 5 Banjarbaru?

Tujuan penelitian ini adalah Membantu peserta didik membentuk karakter dirinya berdasarkan nilai utama karakter prioritas PPK; Membantu meningkatkan animo dan menjawab ekspektasi masyarakat dan orang tua peserta didik atas pembentukan karakter ana-anaknya berdasarkan nilai utama karakter prioritas PPK. Manfaat penelitian ini adalah Menjadikan langkah penting dalam membentuk karakter bagi peserta didik SMPN 5 Banjarbaru; Merupakan langkah nyata untuk mempersiapkan generasi emas tahun 2045 dalam hal pembentukan mental spiritual; Bisa dijadikan rujukan untuk pendidikan karakter pada sekolah-sekolah lain yang akan menerapkan kegiatan yang sama.

\section{METODE}

Aspek yang ditawarkan PENDIKAR dari SMPN 5 Banjarbaru dalam membantu pembentukan karakter peserta didik adalah Iman dan taqwa (turunan nilai religius dan integritas); Akhlak mulia (turunan nilai religius dan integritas); Cinta tanah air (turunan dari nilai nasionalis dan integritas); Cinta lingkungan (turunan dari nilai nasionalis dan religius), dan Kewirausahaan (turunan dari nilai mandiri dan gotong royong).

Sementara itu, rincian kegiatan untuk masing-masing aspek adalah Kegiatan Iman dan Taqwa meliputi Tahsin (Pembentulan Bacaan Al-Qur'an); Tausiyah harian dan bulanan; Pembacaan Surah Yasin, Al-Waqiah, dan Al-Mulk; TPA (Taman Pendidikan Al-Qur'an); Tahfidz (Hafalan Al-Qur'an); Shalat Dhuha; Shalat Dzuhur; Berdoa sebelum dan sesudah pembelajaran.

Akhlak Mulia meliputi 5S Menyambut peserta didik di depan gerbang; Mengucapkan salam ketika memulai dan mengakhiri pembelajaran; Selalu bersalaman ketika berpapasan peserta didik dan guru; Membiasakan tegur sapa ketika berpapasan; Membiasakan senyum ketika berpapasan; Mengedepankan sopan dan santun dalam kegiatan di sekolah.

Cinta Tanah Air, kegiatannya meliputi Upacara bendera setiap hari senin; Upacara bendera ketika hari-hari besar nasional; Memperdengarkan lagu-lagu nasional di awal dan akhir pembelajaran serta ketika waktu istirahat; Mengadakan latihan rutin: Pramuka, Paskibra, PMR dan PKS; Mengadakan lomba menyanyikan lagu-lagu Nasional dan Daerah.

Cinta Lingkungan, kegiatannya meliputi Membersihkan kelas dan lingkungan sekolah; Menanam dan merawat tanaman di dalam dan luar ruangan; Merawat taman yang ada di 
sekolah; Menanam tanaman sayur dan buah; Membiasakan berperilaku sehat dan bersih dengan menyiapkan fasilitas air dan tempat sampah di depan kelasnya; Membersihkan tempat ibadah yang ada di lingkungan sekolah dan di sekitar sekolah.

Kewirausahaan, kegiatannya meliputi Mengadakan Market Day dan Membentuk kelas kewirausahaan.

\section{PELAKSANAAN}

Jadwal penerapan kegiatan PENDIKAR dari SMPN 5 Banjarbaru berupa pembentukan karakter peserta didik adalah Iman dan taqwa (turunan nilai religius dan integritas); Akhlak mulia (turunan nilai religius dan integritas); Cinta tanah air (turunan dari nilai nasionalis dan integritas); Cinta lingkungan (turunan dari nilai nasionalis dan religius), dan Kewirausahaan (turunan dari nilai mandiri dan gotong royong) dilaksanakan setiap hari secara bergantian.

Cara pemecahan masalah melalui tahap perencanaan, yaitu Pembentukan tim pengawas dan penilai implementasi dari masing-masing aspek serta instrument penilaiannya; Melakukan assesmen awal baik pada pembentukan karakter pada peserta didik maupun pada kepuasan orang tua peserta didik terhadap karakter diri anaknya dengan instrument masingmasing; Menyusun rencana aspek dan kegiatan PENDIKAR yang dapat mewakili nilai karakter prioritas PPK; Menyusun jadwal pelaksanaan masing-masing kegiatan, serta sasaran dan anggaran dan perlengkapan yang dibutuhkan.

Sosialisasi pada peserta secara menyeluruh meliputi Implementasi, yaitu Tahap implementasi dilaksanakan sesuai dengan jadwal yang telah disusun dan masing-masing guru yang telah mendapatkan tugas untuk mengawasi dan menilai penerapan masing-masing aspek. Tim guru-guru ditugaskan untuk memastikan implementasi dari aspek dan kegiatan PENDIKAR sudah sesuai dengan jadwal, sasaran dan anggaran maupun perlengkapannya memadai. Tim juga mengisi instrument pelaksanaan PENDIKAR yang telah disusun sebelumnya.

Evaluasi Tim Pengawas implementasi PENDIKAR melaporkan hasil temuan penerapan PENDIKAR pada peserta didik yang dilihat melalui instrument yang telah diisi oleh tim penilai PENDIKAR dan membandingkannya dengan instrument penilaian karakter peserta didik yang telah dibagikan kepada masing-masing orang tua peserta didik. Masing-masing hasil ini juga dibandingkan dengan hasil asesmen awal baik pada peserta didik maupun pada orang tua siswa.

Indikator Keberhasilan dari kegiatan ini adalah minimal peserta didik sudah mendapat predikat BAIK pada masing-masing aspek PENDIKAR dan Minimal orang tua peserta didik sudah mendapat menyatakan PUAS pada masing-masing aspek PENDIKAR.

Perangkat Instrumen yang digunakan adalah Instrument penilaian penguatan karakter berdasarkan nilai utama karakter prioritas PPK (terlampir) dan instrument penilaian kepuasan pembentukan karakter pembelajaran berdasarkan nilai utama karakter prioritas PPK (terlampir). 


\section{HASIL PENELITIAN}

Jadwal penerapan kegiatan PENDIKAR dari SMPN 5 Banjarbaru berupa pembentukan karakter peserta didik adalah sebagai berikut:

Tabel 1. Jadwal Kegiatan PENDIKAR SMPN 5 Banjarbaru

\begin{tabular}{|c|c|c|c|c|c|}
\hline No. & Karakter & Jenis Kegiatan & Jam & $\begin{array}{c}\text { Waktu } \\
\text { Pelaksanaan }\end{array}$ & Keterangan \\
\hline \multirow[t]{8}{*}{1} & $\begin{array}{l}\text { IMAN DAN } \\
\text { TAKWA }\end{array}$ & $\begin{array}{l}\text { Tahsin } \\
\text { (Pembetulan } \\
\text { Bacaan Al-Qur'an) }\end{array}$ & $07.30-08.00$ & $\begin{array}{l}\text { Selasa, Rabu, } \\
\text { Kamis }\end{array}$ & $\begin{array}{l}\text { Tiap tingkat } \\
\text { bergiliran } \\
(7,8,9)\end{array}$ \\
\hline & & $\begin{array}{l}\text { Tausiyah harian } \\
\text { dan bulanan }\end{array}$ & $07.30-08.00$ & $\begin{array}{l}\text { Selasa, Rabu, } \\
\text { Kamis }\end{array}$ & $\begin{array}{l}\text { Tiap tingkat } \\
\text { bergiliran } \\
(7,8,9)\end{array}$ \\
\hline & & $\begin{array}{l}\text { Pembacaan Surah } \\
\text { Yasin, Al-Waqiah, } \\
\text { dan Al-Mulk }\end{array}$ & $07.30-08.00$ & $\begin{array}{l}\text { Selasa, Rabu, } \\
\text { Kamis }\end{array}$ & $\begin{array}{l}\text { Tiap tingkat } \\
\text { bergiliran } \\
(7,8,9)\end{array}$ \\
\hline & & $\begin{array}{l}\text { TPA (Taman } \\
\text { Pendidikan Al- } \\
\text { Qur'an) }\end{array}$ & $15.00-16.30$ & $\begin{array}{l}\text { Senin, } \\
\text { Selasa, Rabu, } \\
\text { Kamis }\end{array}$ & $\begin{array}{l}\text { Dipilih siswa } \\
\text { yang belum } \\
\text { bisa membaca } \\
\text { Al-Qur'an }\end{array}$ \\
\hline & & $\begin{array}{l}\text { Tahfidz (Hafalan } \\
\text { Al-Qur'an) }\end{array}$ & $15.00-16.30$ & $\begin{array}{l}\text { Senin, } \\
\text { Selasa, Rabu, } \\
\text { Kamis }\end{array}$ & $\begin{array}{l}\text { Dipilih siswa } \\
\text { yang belum } \\
\text { bisa membaca } \\
\text { Al-Qur'an }\end{array}$ \\
\hline & & Shalat Dhuha & $07.30-08.00$ & $\begin{array}{l}\text { 1. Harian, } \\
\text { sesuai } \\
\text { jadwal } \\
\text { Mapel BTA } \\
\text { 2. Bulanan } \\
\text { dilaksanaka } \\
\text { n setiap hari } \\
\text { Jum'at ke-3 }\end{array}$ & $\begin{array}{l}\text { Seluruh siswa, } \\
\text { di lapangan }\end{array}$ \\
\hline & & Shalat Dzuhur & $12.30-13.00$ & $\begin{array}{l}\text { Setiap hari } \\
\text { (seluruh } \\
\text { siswa) }\end{array}$ & $\begin{array}{l}\text { Siswa dan } \\
\text { siswi dipisah }\end{array}$ \\
\hline & & $\begin{array}{l}\text { Berdoa sebelum } \\
\text { dan sesudah } \\
\text { pembelajaran }\end{array}$ & $\begin{array}{l}08.00 \\
15.00 \\
16.30\end{array}$ & $\begin{array}{l}\text { Setiap hari } \\
\text { (di setiap } \\
\text { kelas) }\end{array}$ & \\
\hline \multirow[t]{3}{*}{2} & $\begin{array}{l}\text { AKHLAK } \\
\text { MULIA }\end{array}$ & $\begin{array}{l}\text { Menyambut siswa } \\
\text { di depan gerbang }\end{array}$ & $07.00-07.30$ & Setiap hari & $\begin{array}{l}\text { Petugas: Guru } \\
\text { Piket }\end{array}$ \\
\hline & & $\begin{array}{l}\text { Mengucapkan } \\
\text { salam ketika } \\
\text { memulai dan } \\
\text { mengakhiri } \\
\text { pembelajaran }\end{array}$ & $\begin{array}{l}08.00 \\
15.00\end{array}$ & Setiap hari & \\
\hline & & $\begin{array}{l}\text { Selalu bersalaman } \\
\text { ketika berpapasan } \\
\text { siswa dan guru }\end{array}$ & & Setiap hari & Pembiasaan \\
\hline
\end{tabular}




\begin{tabular}{|c|c|c|c|c|c|}
\hline & & $\begin{array}{l}\text { Membiasakan } \\
\text { tegur sapa ketika } \\
\text { berpapasan }\end{array}$ & & Setiap hari & Pembiasaan \\
\hline & & $\begin{array}{l}\text { Membiasakan } \\
\text { senyum ketika } \\
\text { berpapasan }\end{array}$ & & Setiap hari & Pembiasaan \\
\hline & & $\begin{array}{l}\text { Mengedepankan } \\
\text { sopan dan santun } \\
\text { dalam kegiatan di } \\
\text { sekolah }\end{array}$ & & Setiap hari & Pembiasaan \\
\hline \multirow[t]{9}{*}{3} & CINTA TANAH & Upacara Bendera & & Setiap hari & \\
\hline & AIR & & $07.30-08.00$ & Senin & \\
\hline & & Upacara Bendera & $07.30-08.00$ & $\begin{array}{l}\text { Setiap hari } \\
\text { besar } \\
\text { Nasional }\end{array}$ & \\
\hline & & $\begin{array}{l}\text { Memperdengarka } \\
\mathrm{n} \text { lagu-lagu } \\
\text { nasional di awal } \\
\text { dan akhir } \\
\text { pembelajaran } \\
\text { serta ketika waktu } \\
\text { istirahat }\end{array}$ & $\begin{array}{l}\text { Jam istirahat, } \\
\text { jam pulang }\end{array}$ & Setiap hari & \\
\hline & & $\begin{array}{l}\text { Mengadakan } \\
\text { latihan rutin: } \\
\text { Pramuka, } \\
\text { Paskibra, PMR } \\
\text { dan PKS }\end{array}$ & $15.30-17.30$ & $\begin{array}{l}\text { Sesuai } \\
\text { jadwal } \\
\text { latihan }\end{array}$ & \\
\hline & & Mengadakan & & Saat hari & \\
\hline & & lomba & & besar & \\
\hline & & menyanyikan & & Nasional & \\
\hline & & $\begin{array}{l}\text { lagu-lagu Nasional } \\
\text { dan Daerah }\end{array}$ & & & \\
\hline \multirow[t]{6}{*}{4} & CINTA & Membersihkan & $07.00-07.30$ & Setiap hari & \\
\hline & LINGKUNGAN & $\begin{array}{l}\text { kelas dan } \\
\text { lingkungan } \\
\text { sekolah }\end{array}$ & & & \\
\hline & & $\begin{array}{l}\text { Menanam dan } \\
\text { merawat tanaman } \\
\text { di dalam dan luar } \\
\text { ruangan }\end{array}$ & Jam istirahat & $\begin{array}{l}\text { Setiap hari } \\
\text { sesuai } \\
\text { jadwal piket }\end{array}$ & \\
\hline & & $\begin{array}{l}\text { Merawat taman } \\
\text { yang ada di } \\
\text { sekolah }\end{array}$ & Jam istirahat & $\begin{array}{l}\text { Setiap satu } \\
\text { bulan sekali }\end{array}$ & \\
\hline & & $\begin{array}{l}\text { Menanam } \\
\text { tanaman sayur } \\
\text { dan buah }\end{array}$ & Jam istirahat & $\begin{array}{l}\text { Tiga bulan } \\
\text { sekali }\end{array}$ & \\
\hline & & $\begin{array}{l}\text { Membiasakan } \\
\text { berperilaku sehat } \\
\text { dan bersih dengan }\end{array}$ & $\begin{array}{l}\text { Awal masuk } \\
\text { Istirahat } \\
\text { Pulang }\end{array}$ & Setiap hari & \\
\hline
\end{tabular}




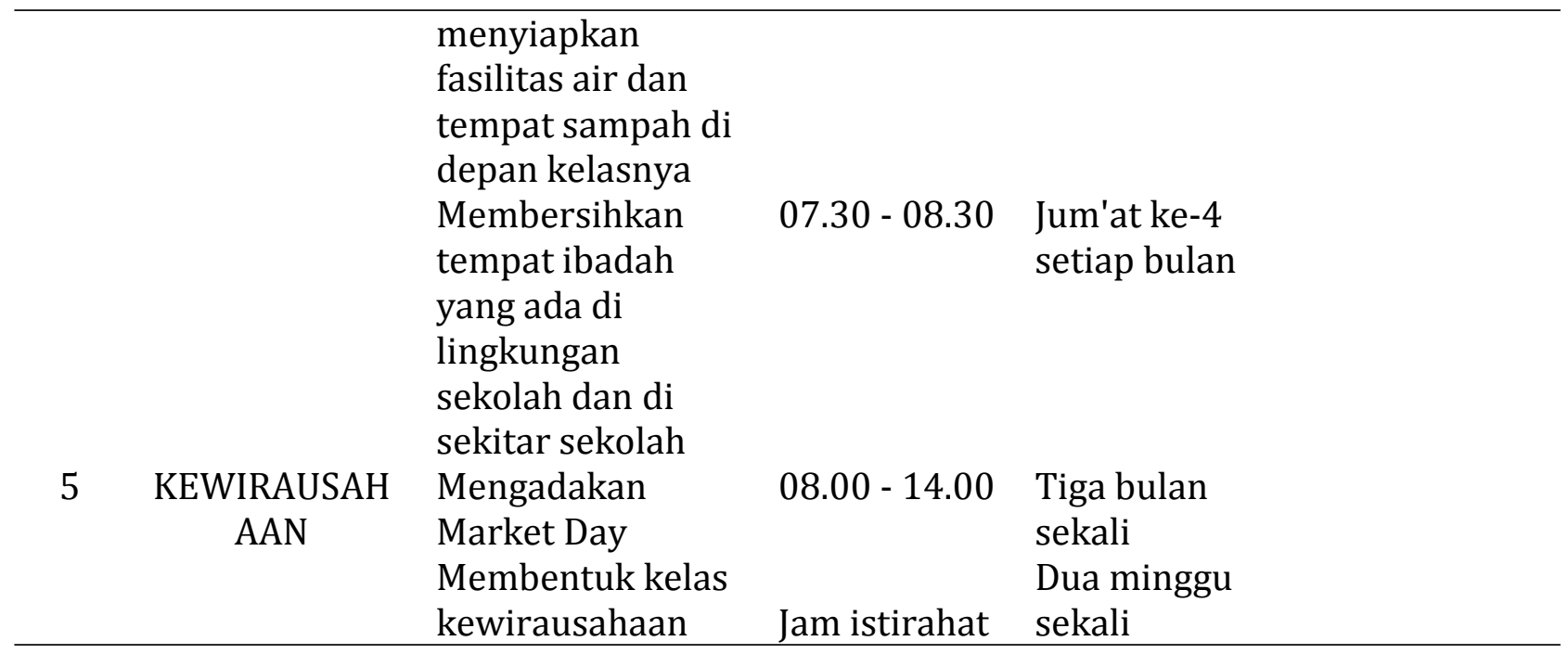

Persentase penguatan karakter yang diperoleh kemudian dikorelasikan dengan kategori penilaian penguatan karakter seperti tercantum pada tabel di bawah ini:

Tabel 2. Persentase Penguatan Karakter

\begin{tabular}{ccc}
\hline No. & Rentang $\%$ & Kategori \\
\hline 1 & $91 \%-100 \%$ & Sangat Baik \\
2 & $76 \%-90 \%$ & Baik \\
3 & $61 \%-75 \%$ & Cukup \\
4 & $51 \%-60 \%$ & Kurang \\
5 & $<51 \%$ & Buruk \\
\hline
\end{tabular}

Keadaan Awal meliputi Karakter Diri Peserta Didik berdasarkan asesmen awal pada peserta didik didapatkan hasil yaitu Pada nilai Religius, peserta didik belum menerapkan konsep religius pada kehidupan sehari-hari seperti mengucapkan salam, masih ada siswa yang kurang lancar saat praktik shalat dalam mata pelajaran agama, hingga masih adanya peserta didik yang belum bisa baca tulis Al-Qur'an dan skor yang didapat hanya mencapai 55\% (Cukup); Pada nilai Integritas, peserta didik masih banyak yang tercatat belum mengerjakan tugas rumah, serta masih banyak ditemukan kecurangan saat ujian. Nilai integritas hanya mencapai 65\% (Cukup); Pada nilai Nasionalis, peserta didik masih banyak yang terlihat tidak serius saat upacara bendera, bercanda saat lagu Indonesia Raya berkumandang, dan banyak yang tidak hormat saat bendera dinaikkan. Nilai Nasionalis hanya mencapai 70\% (Cukup); Pada nilai Gotong Royong, masih banyak peserta didik yang terlihat membolos piket harian dan membiarkan temannya melakukan pekerjaan berat sendiri seperti memindahkan pot, bangku atau meja. Nilai gotong royong hanya mencapai angka $65 \%$ (Cukup); Pada nilai Mandiri, peserta didik juga masih banyak yang tercatat mencontek saat ujian berlangsung dan saat kerja kelompok di dalam kelas hanya mengandalkan jawaban dari hasil diskusi teman kelompoknya. Nilai Mandiri hanya mencapai angka 70\% (Cukup);

Kepuasan orang tua pada peserta didik hanya mencapai angka 65\% pada nilai Religius, $65 \%$ pada nilai Integritas, $70 \%$ pada nilai Nasionalis, 70\% pada nilai Gotong Royong, 65\% pada nilai Mandiri. 
Kondisi Setelah Penerapan PENDIKAR pada karakter peserta didik meliputi Nilai religious terpantau mengalami peningkatan sebesar $45 \%$ atau mengalami peningkatan pencapaian menjadi $80 \%$ digambarkan dengan grafik berikut ini

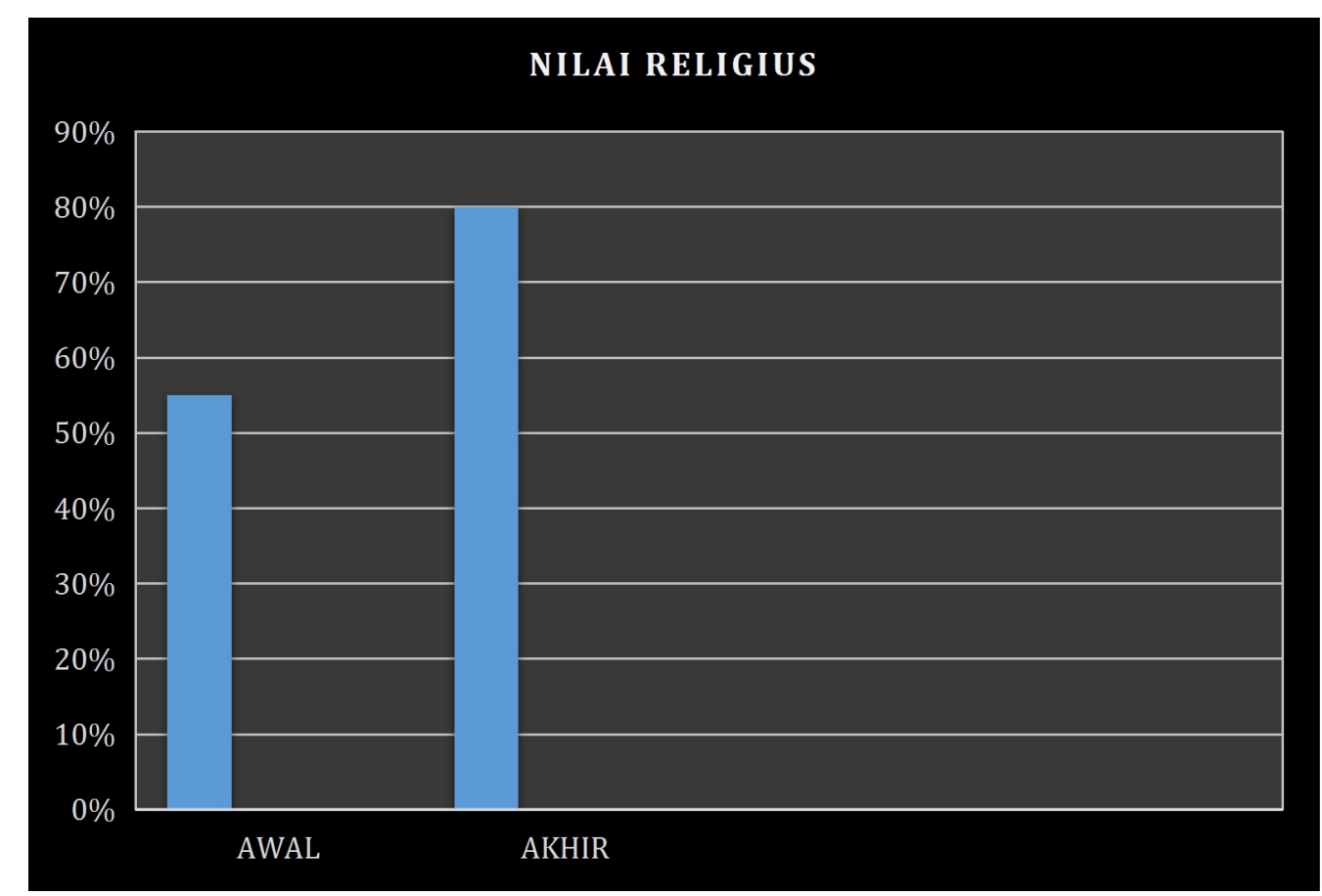

Gambar 1. Nilai religius Peserta Didik

Sedangkan Nilai integritas terpantau mengalami peningkatan sebesar $41,67 \%$ atau mengalami peningkatan pencapaian menjadi 85\% digambarkan dengan gambar berikut ini.

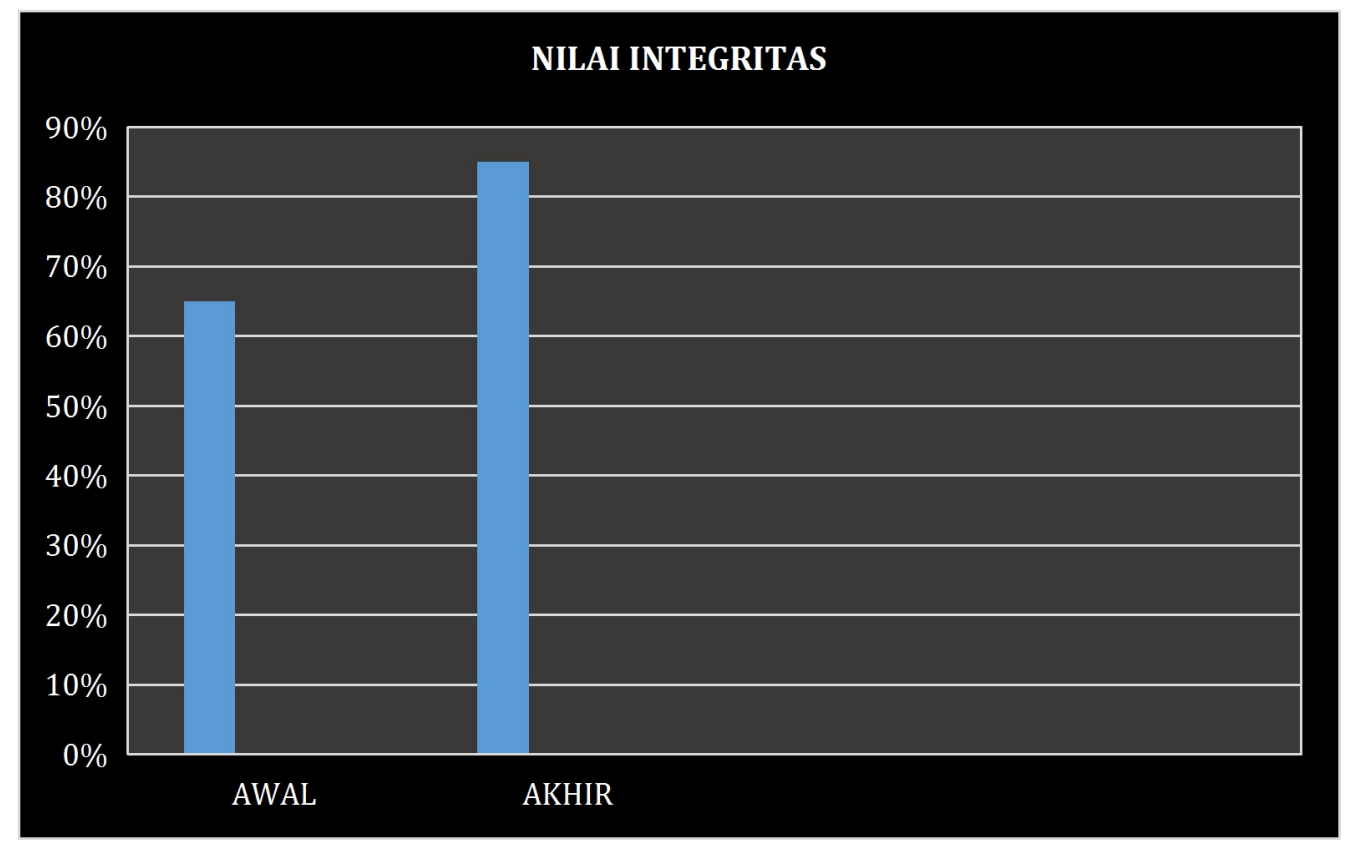

Gambar 2. Nilai Integritas Peserta Didik 
Nilai nasionalis terpantau mengalami peningkatan sebesar $21,43 \%$ atau mengalami peningkatan pencapaian menjadi $85 \%$ digambarkan dengan grafik berikut ini:

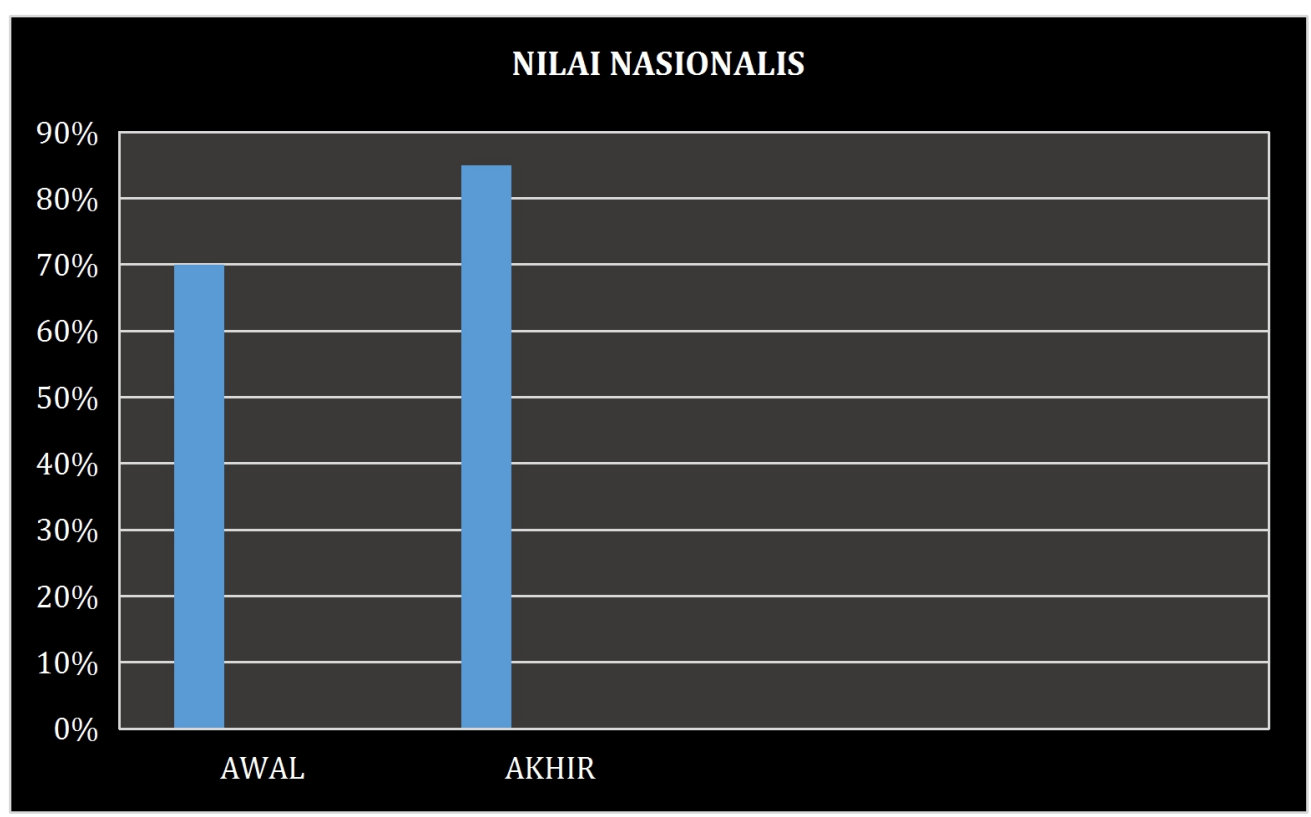

Gambar 3. Nilai Nasionalis Peserta Didik

Nilai gotong royong terpantau mengalami peningkatan sebesar 23,08\% atau mengalami peningkatan pencapaian menjadi $80 \%$ digambarkan dengan grafik berikut ini.

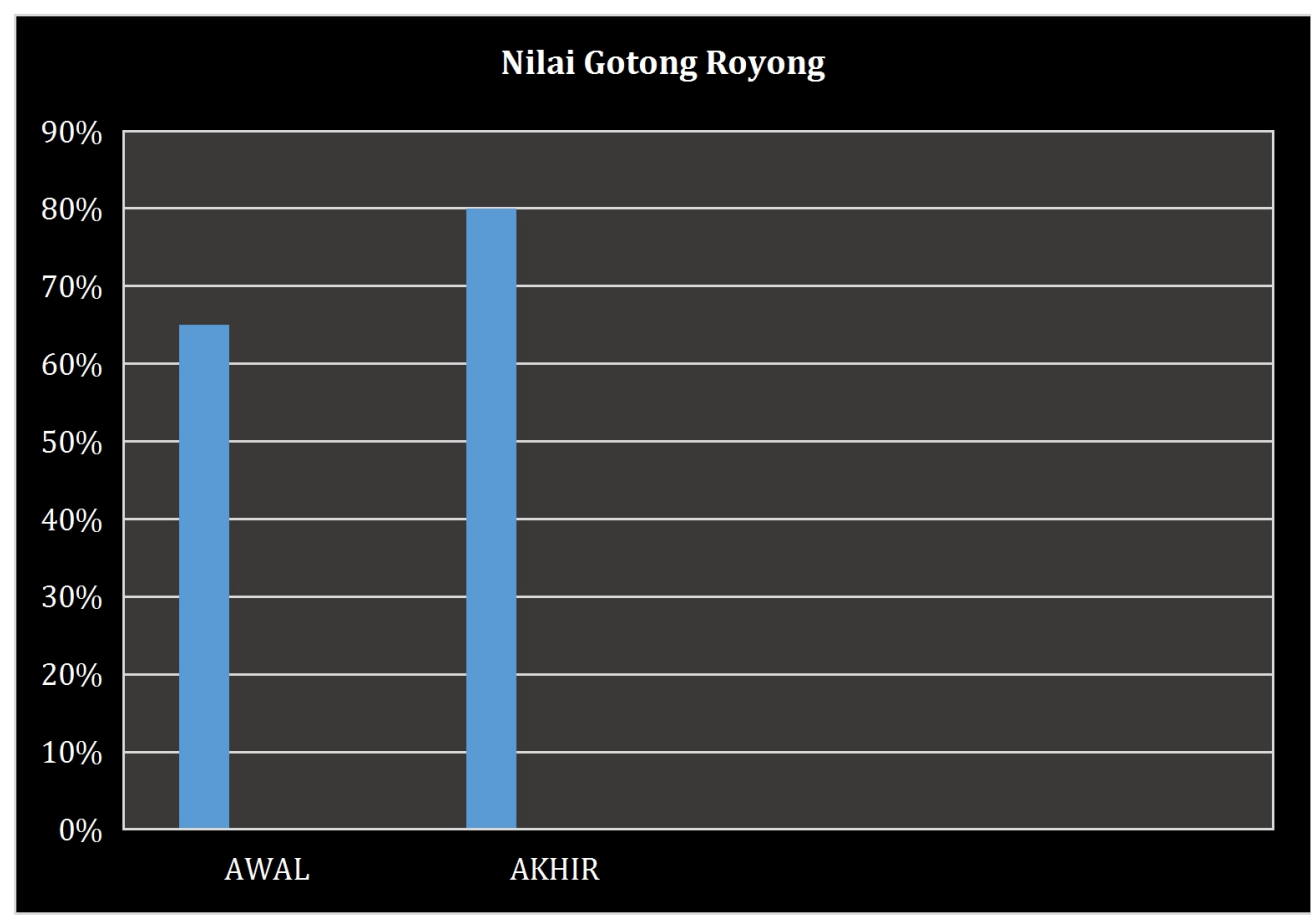

Gambar 4. Nilai Gotong Royong Peserta Didik 
Nilai Mandiri terpantau mengalami peningkatan sebesar $14,29 \%$ atau mengalami peningkatan pencapaian menjadi 80\% digambarkan dengan grafik berikut ini.

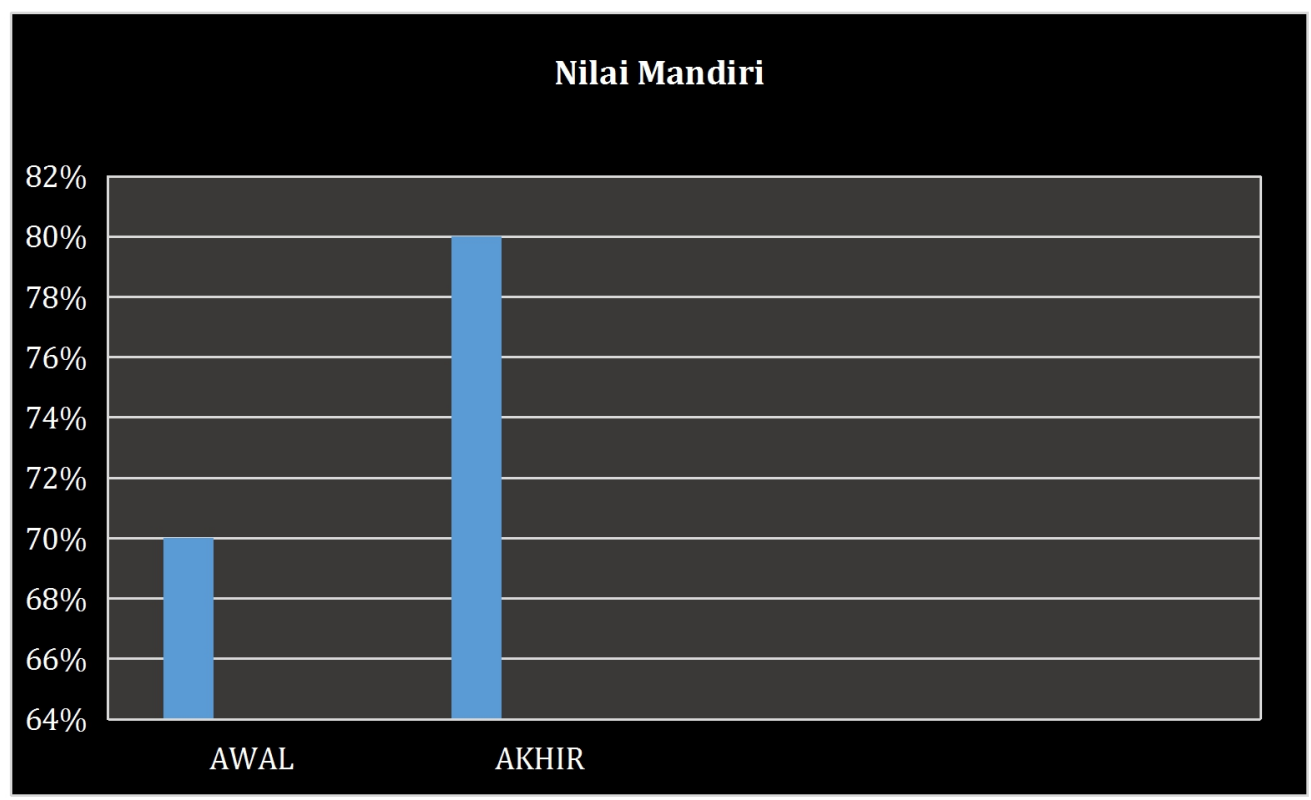

Gambar 5. Nilai Mandiri Peserta Didik

Kepuasan Orang Tua pada Karakter Anak meliputi nilai-nilai berikut ini. Nilai religius terpantau mengalami peningkatan sebesar $15,38 \%$ atau mengalami peningkatan pencapaian menjadi 75\% dengan grafik berikut ini.

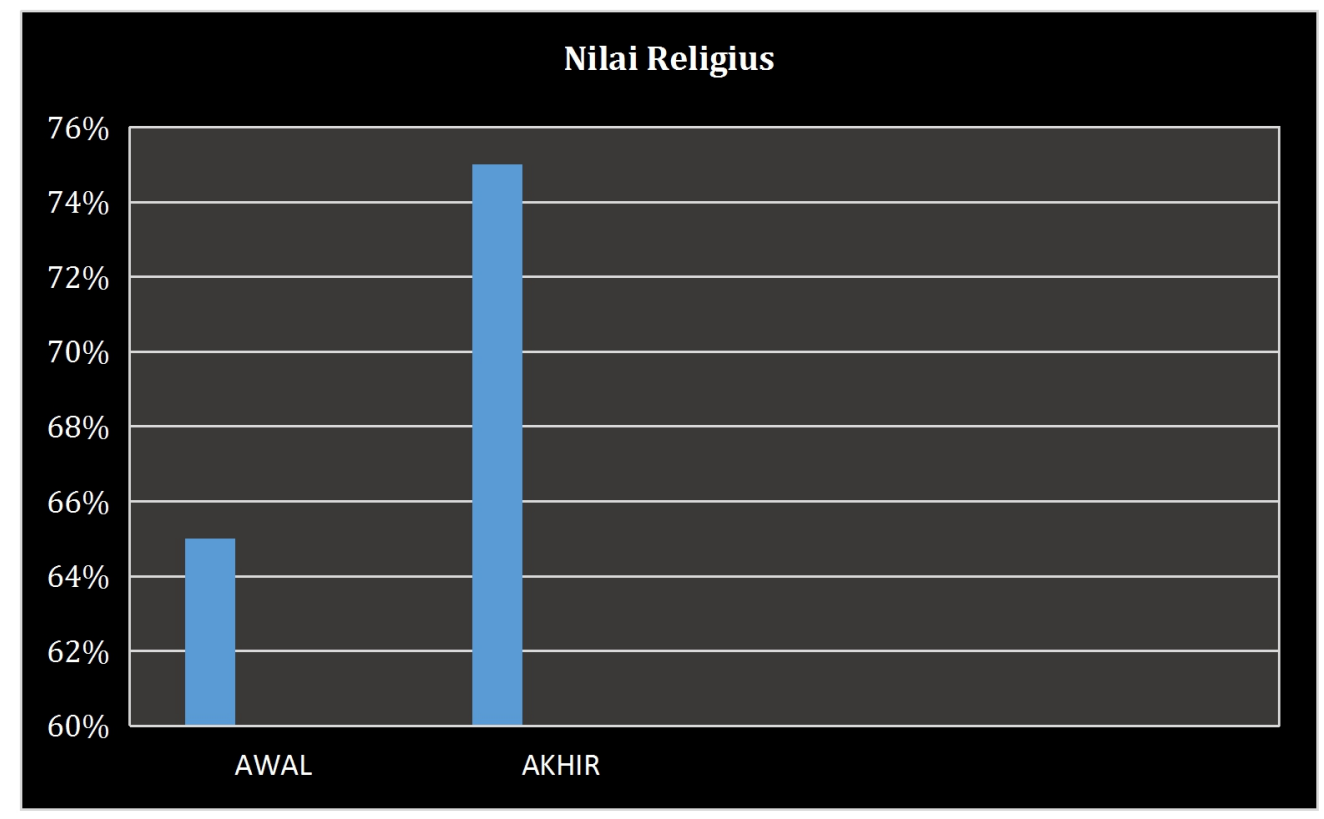

Gambar 6. Nilai religius Kepuasan Orang Tua pada Karakter Anak 
Nilai integritas terpantau mengalami peningkatan sebesar $30,77 \%$ atau mengalami peningkatan pencapaian menjadi 85\% dengan grafik berikut ini.

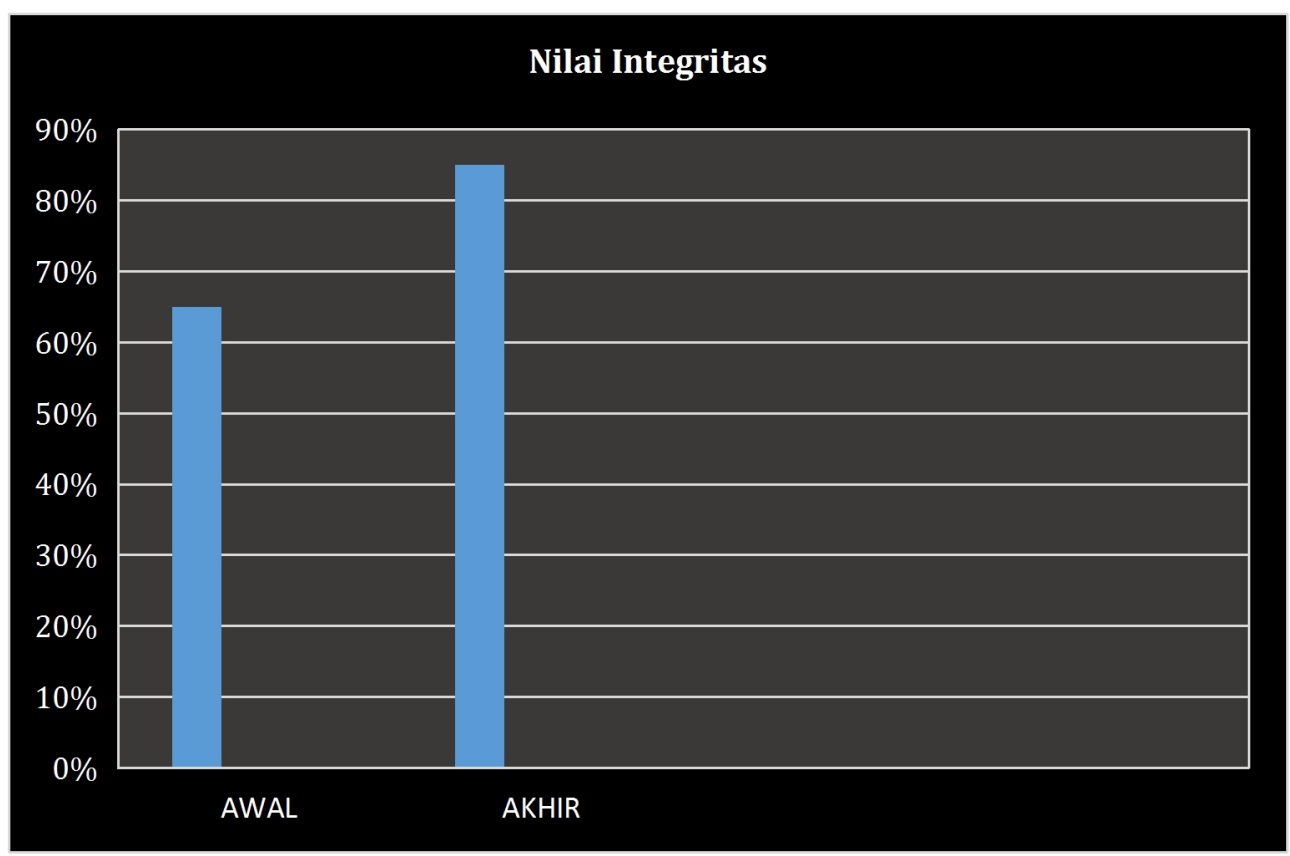

Gambar 7. Nilai Integritas Kepuasan Orang Tua pada Karakter Anak

Nilai nasionalis terpantau mengalami peningkatan sebesar $14,23 \%$ atau mengalami peningkatan pencapaian menjadi $80 \%$ dengan grafik berikut ini.

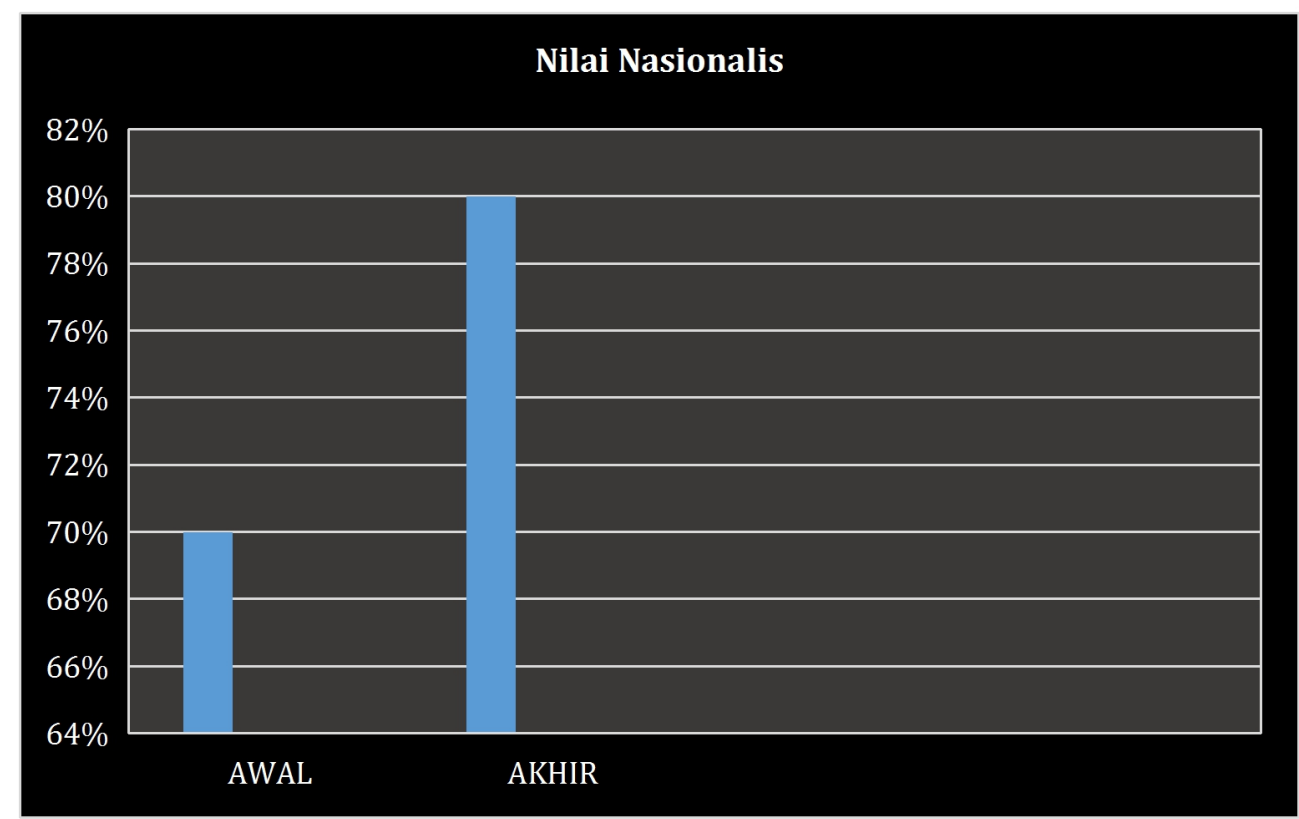

Gambar 8. Nilai Nasionalis Kepuasan Orang Tua pada Karakter Anak 
Nilai gotong royong terpantau mengalami peningkatan sebesar 21,43\% atau mengalami peningkatan pencapaian menjadi 85\% dengan grafik berikut ini.

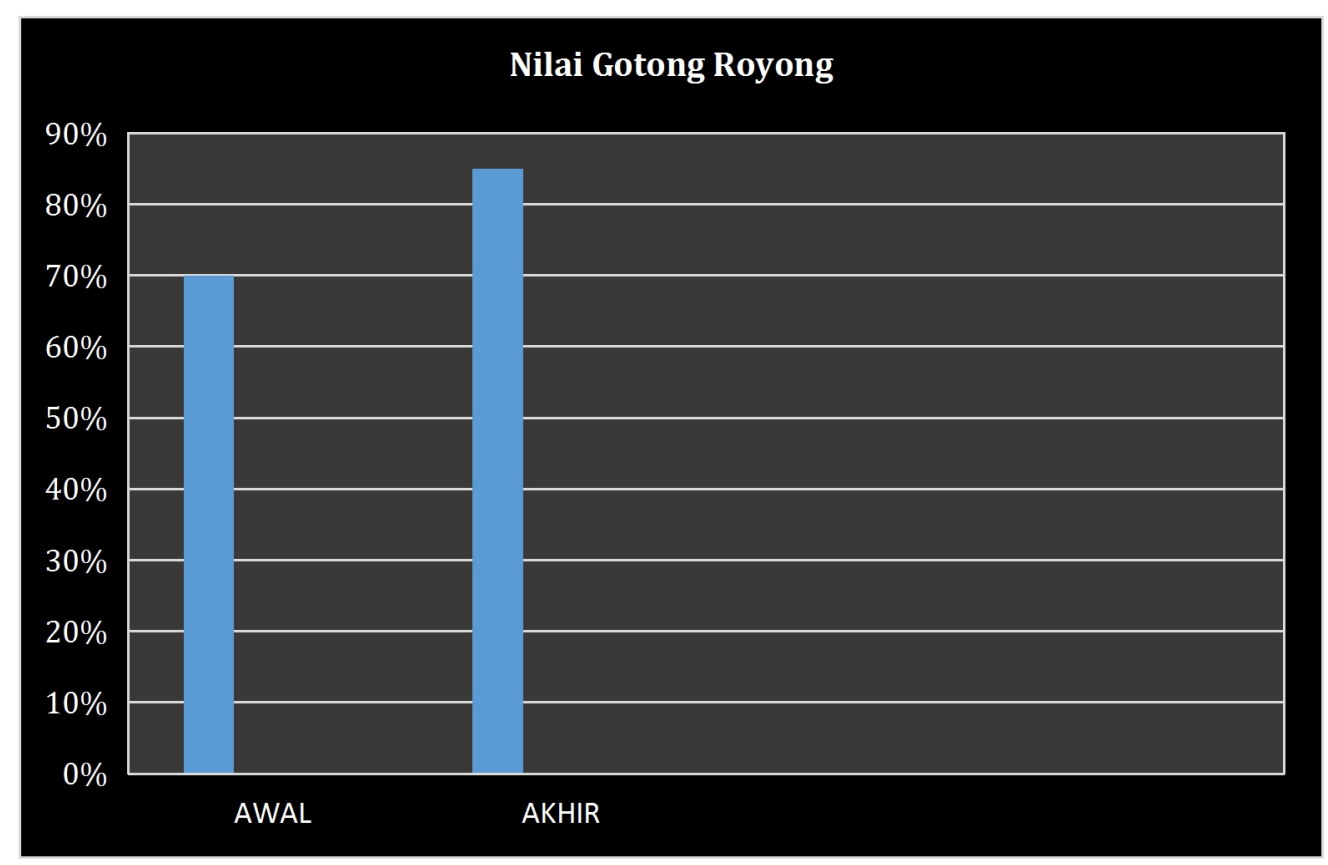

Gambar 9. Nilai Gotong Royong Kepuasan Orang Tua pada Karakter Anak

Nilai Mandiri terpantau mengalami peningkatan sebesar 30,77\% atau mengalami peningkatan pencapaian menjadi $85 \%$ dengan grafik berikut ini.

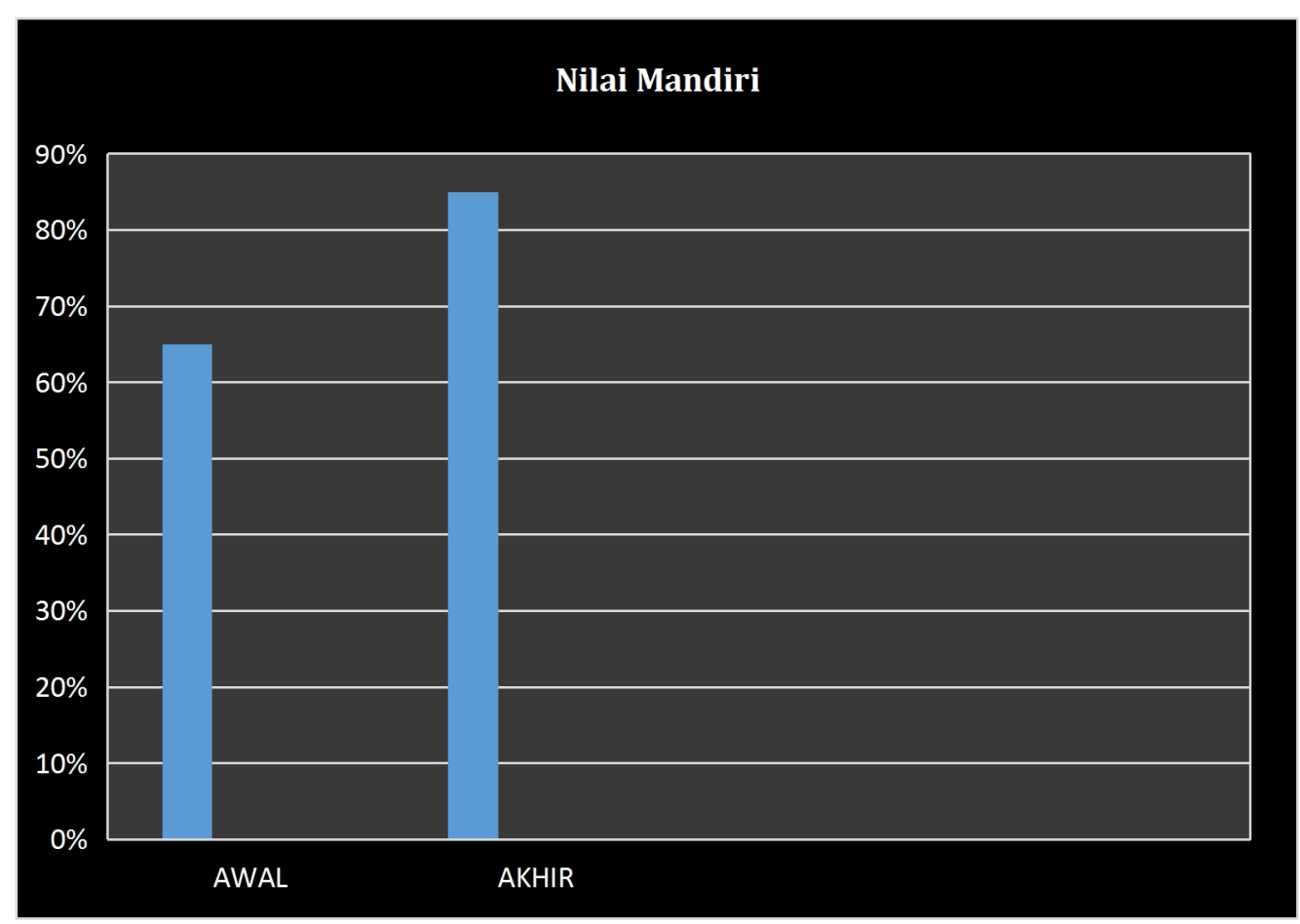

Gambar 10. Nilai Mandiri Kepuasan Orang Tua pada Karakter Anak 


\section{DAFTAR PUSTAKA}

Mashud, M. (2015). Pendekatan Pembelajaran Pendidikan Jasmani Olahraga dan Kesehatan di Era Abad 21. Jurnal Multilateral, 14(2), 89-196.

https://doi.org/10.20527/multilateral.v14i2.2471.g2172

Prayitno dan Belferik Manullang. Pendidikan Karakter dalam Pembangunan Bangsa. Jakarta: Grasindo, 2011

Republik Indonesia, Peraturan Pemerintah Nomor 17 tahun 2010 tentang Pengelolaan Penyelenggaraan Pendidikan.

Republik Indonesia, Peraturan Pemerintah Nomor 19 Tahun 2005 tentang Standar Nasional Pendidikan.

Republik Indonesia, Peraturan Menteri Pendidikan Nasional Nomor 22 Tahun 2006 tentang Standar Isi Pendidikan Dasar dan Menengah.

Republik Indonesia, Peraturan Menteri Pendidikan Nasional Nomor 27 Tahun 2008 tentang Standar Kualifikasi Akademik dan Kompetensi Guru.

Republik Indonesia, Peraturan Pemerintah Nomor 17 tahun 2010 tentang Pengelolaan Penyelenggaraan Pendidikan.

Republik Indonesia, Undang-undang RI Nomor 20 Tahun 2003 tentang Sistem Pendidikan Nasional.

Pusat Kurikulum dan Perbukuan. 2011. Pedoman Pelaksanaan Pendidikan Karakter. Badan Penelitian dan Pengembangan Kementrian Pendidikan Nasional. Jakarta.

Samani, M., \& Hariyanto. 2011. Konsep dan Model Pendidikan Karakter. Rosda Karya. Bandung. Suryadi. 2021. Menerapkan Pendidikan Karakter di Sekolah. Mentari Pustaka. Yogyakarta. 